\title{
Intimacy Istri dalam Pernikahan
}

\author{
Anggia Wahyu Agustin, Asmidir Ilyas, Ifdil \\ IICET, Universitas Negeri Padang, Universitas Negeri Padang \\ *) Correspondence e-mail: anggiawahyuagustin0303@gmail.com,
}

\begin{abstract}
Intimacy merupakan suatu hal yang penting dalam pernikahan. Namun, pada kenyataannya intimacy banyak diabaikan oleh pasangan yang telah menikah. Pernikahan yang didasari dengan intimacy akan menciptakan komitmen yang baik dalam pernikahan. Penelitian ini menggunakan subjek penelitian sebanyak 42 orang dengan teknik analisis deskriptif. intimacy merupakan bagian yang mendorong individu untuk lebih akrab, saling menghargai dan percaya serta adanya kedekatan emosional dengan pasangan
\end{abstract}

Keywords: intimacy

Article History: Received on 02/02/2018; Revised on 02/03/2018; Accepted on 15/03/2018; Published Online: 30/03/2018.

(4) This is an open access article distributed under the Creative Commons Attribution License, which permits unrestricted use,
distribution, and reproduction in any medium, provided the original work is properly cited. (C2018 by author.

Manusia adalah makhluk ciptaan Allah Yang Maha Esa dengan kemampuan yang sangat sempurna bila dibandingkan dengan makhluk Tuhan lainnya. Manusia diciptakan sebagai makhluk multidimensional, memiliki akal pikiran dan kemampuan berinteraksi secara personal maupun sosial. Manusia merupakan makhluk sosial, maka pada dasarnya tidak mampu hidup sendiri di dalam dunia ini baik sendiri dalam konteks fisik maupun dalam konteks sosial budaya (Bungin, 2013:25).

Manusia sebagai makhluk sosial akan sangat berguna dan bermanfaat bagi manusia lainnya karena memerlukan interaksi dalam hidupnya. Setiap manusia akan mencapai usia dewasa dalam hidupnya. Masa dewasa menggambarkan segala organ yang telah matang yang merujuk pada manusia. Masa dewasa adalah masa yang paling lama dalam rentang kehidupan. Masa dewasa biasanya dimulai sejak usia 18 tahun hingga kira-kira usia 40 tahun yang biasanya ditandai dengan selesainya masa pubertas dan mampu untuk bereproduksi. Masa dewasa dikatakan sebagai masa sulit bagi individu karena pada masa ini seseorang dituntut untuk melepaskan ketergantungannya terhadap orangtua dan berusaha untuk dapat mandiri (Jahja, 2012: 245).

Pernikahan pada hakikatnya bukan hanya untuk melegalkan hubungan biologis namun juga membentuk suatu kehidupan baru yaitu keluarga yang menuntut kedua pihak (suami dan istri) untuk mampu mandiri dalam menyikapi berbagai kejadian atau masalah dalam pernikahan (Naibaho, 2013).

Kedekatan atau intimacy adalah kemampuan untuk berbaur dengan orang lain tanpa ada rasa takut dan dapat dicapai jika sudah membentuk ego yang stabil serta 
memiliki rasa percaya dengan orang lain. Hal ini melibatkan pengorbanan, kompromi, dan komitmen pada hubungan yang telah dibina (Feist \& Feist, 2014:307).

Untuk memperoleh kebahagiaan dalam perkawinan, Hurlock (1980: 299) mengemukakan pasangan suami istri akan memperoleh kebahagiaan bersama dan memperoleh kepuasan dengan adanya cinta yang mantap satu sama lainnya. Peran suami istri dalam menjalani kehidupan perkawinan dipengaruhi oleh hubungan interpersonal yang dilakukan.

\section{METODE}

Menurut Lehmann (dalam Yusuf, 2014: 61) "penelitian deskriptif adalah salah satu jenis penelitian yang bertujuan untuk mendeskripsikan secara sistematis, faktual, dan akurat menganai fakta-fakta dan sifat populasi tertentu atau mencoba menggambarkan fenomena secara mendetail. Menurut Idrus (2009:91) subjek penelitian adalah individu, benda, atau organisme yang dijadikan sumber informasi yang dibutuhkan dalam pengumpulan data penelitian. Senada dengan itu, Arikunto (2016:88) mengatakan subjek penelitian adalah benda, hal atau orang tempat data untuk variabel penelitian melekat dan yang dipermasalahkan.

\section{HASIL DAN PEMBAHASAN}

\section{INTIMACY ISTRI DI KECAMATAN HAMPARAN RAWANG KOTA SUNGAI PENUH}

\section{BENTUK UMUM INTIMACY ISTRI DI KECAMATAN HAMPARAN RAWANG KOTA SUNGAI PENUH}

Berdasarkan hasil temuan penelitian mengenai intimacy istri di Kecamatan Hamparan Rawang Kota Sungai Penuh secara umum berada pada kategori intim yang berkaitan dengan aspek pengorbanan, kompromi dan komitmen. Artinya, intimacy istri berada pada kategori intim. Buktinya yaitu adanya istri yang dirawat oleh pasangannya ketika sakit, memberikan semangat kepada pasangan ketika mengalami hambatan dalam pekerjaan.

Hal ini sesuai dengan pendapat, Larsen \& Buss (2018:312) intimacy dengan pasangan merupakan hal yang penting karena hubungan yang dijalin hendaknya memiliki kedekatan emosional seperti kepedulian, saling menjaga dalam hubungan pernikahan. Intimacy ini akan meningkat karena adanya kedekatan dan banyaknya pemberian perhatian salah satunya ketika sakit maka ia akan dirawat dan dijaga oleh pasangannya. Sejalan dengan itu, teori Erikson dalam Papalia, dkk (2008:684) menyatakan perempuan lebih memiliki kemampuan sosial yang positif sehingga mudah melakukan intimacy, ia mampu bertanggung jawab dan memiliki kemampuan untuk memperhatikan orang lain dan dirinya sendiri, dalam hal ini ia mampu memberikan semangat kepada pasangannya dalam menjalankan aktivitas ataupun pekerjaan.

Selanjutnya, Wiley \& Sons (2008:571) menyatakan intimacy merupakan bentuk kemampuan interpersonal dengan pasangan dalam pernikahan yang ditandai dengan adanya kedekatan emosional, sehingga mampu mengungkapkan diri, interaksi yang baik, dan memberikan perhatian dan rasa hormat kepada pasangan. Dalam Mashek (2004) 
intimacy merupakan kebutuhan manusia untuk tetap memelihara keterikatan hubungan dengan pasangannya.

Intimacy Pada Setiap Aspek yang dimiliki Istri di Kecamatan Hamparan Rawang Kota Sungai Penuh

\section{Intimacy Berkaitan dengan Aspek Pengorbanan}

Berdasarkan hasil temuan penelitian mengenai intimacy istri berkaitan dengan aspek pengorbanan di Kecamatan Hamparan Rawang Kota Sungai Penuh secara umum berada pada kategori intim. Artinya, intimacy suami berada pada kategori intim. Dalam hal ini ditemukan bahwa adanya istri yang dirawat oleh suaminya ketika sakit, dibantu oleh pasangan ketika mengalami kesulitan, dan pasangan yang peduli terhadap dirinya.

Menurut Erikson (dalam Papalia, dkk, 2008:684) hubungan yang intim menuntut adanya pengorbanan yaitu adanya kemampuan merespon terhadap pasangan, memberikan perhatian sehingga dapat membuat keadaan menjadi nyaman dalam hubungan yang dibina, saling berbagi informasi dengan pasangan dalam menyelesaikan permasalahan yang tengah dialami, dan memberikan respon kepada pasangan ketika membutuhkannya serta saling bertukar pengalaman dalam menghadapi berbagai persoalan.

\section{Intimacy Berkaitan dengan Aspek Kompromi}

Berdasarkan hasil temuan penelitian mengenai intimacy istri berkaitan dengan aspek kompromi di Kecamatan Hamparan Rawang Kota Sungai Penuh secara umum berada pada kategori intim. Artinya, intimacy suami berada pada kategori intim. Buktinya yaitu adanya istri yang berbincang-bincang dengan pasangan untuk kesiapan masa depan, adanya istri yang menyampaikan hal-hal yang sebaiknya dihindari agar tidak bertengkar.

Menurut Erikson (dalam Papalia, dkk, 2008:685) kompromi yang dilakukan berguna untuk mencapai tujuan yang telah ditetapkan. Hal itu berupa otonomi, kesiapan memiliki anak dan segala keperluan anak, dan mempererat hubungan dengan pasangan sehingga terhindar dari berbagai konflik. Kompromi yang dilakukan harus memperoleh hasil yang baik demi hubungan pernikahannya. Kompromi juga mencakup mengenai kebiasaan, sikap dan aktivitas yang dilalui dalam kehidupan pernikahan.

\section{Intimacy Berkaitan dengan Aspek Komitmen}

Temuan penelitian mengenai intimacy istri berkaitan dengan aspek komitmen di Kecamatan Hamparan Rawang Kota Sungai Penuh secara umum berada pada kategori intim. Artinya, intimacy suami berada pada kategori intim. Hal ini ditandai dengan adanya istri memberikan semangat kepada pasangan ketika mengalami hambatan dalam bekerja, menata keadaan rumah bersama pasangan ketika ada waktu luang, menenangkan pasangan ketika marah dan berhati-hati dalam menyampaikan kekecewaan kepada pasangan agar tidak tersinggung.

Menurut Erikson (dalam Papalia, dkk, 2008: 694) komitmen yang dijalankan dalam hubungan hendaknya mampu menngatur emosi terutama dalam menanggapi permasalahan yang dilami oleh pasangan dan mampu melakukan penyelesaian konflik dengan pasangan. Selain itu, komitmen yang diterapkan akan mampu membentuk hubungan yang kuat dan saling peduli serta saling membantu satu sama lainnya. Komitmen yang dijalankan membuat hubungan menjadi dekat dan saling membahagiakan. Senada dengan itu, Ningrum (2017) menyatakan bahwa komitmen 
dalam pernikahan yang telah dibuat hendaknya dijaga dan ditaati untuk menghindari konflik. Komitmen yang disepakati akan membuat pasangan saling mengakui dan menjaga hubungan mereka.

\section{KESIMPULAN}

Secara umum dapat dipahami bahwa intimacy istri berada pada kategori intim yang berkaitan dengan aspek pengorbanan, kompromi dan komitmen. Kedekatan atau intimacy membangun adanya identitas untuk mampu menghadapi kesulitan, meningkatkan kemandirian, membangun hubungan relasi yang intim dengan individu lain, dan meningkatkan komitmen dalam hubungan yang terjalin serta adanya tuntutan untuk mampu berpikir secara mandiri tanpa bergantung pada orang lain. Jika kedekatan atau intimacy dalam pernikahan tidak terjadi maka dapat menimbulkan ketidakpuasan dan koflik, perceraian, siksaan emosional, ancaman dan tidak terpenuhi kebutuhan anak.

\section{REFERENCES}

Arikunto, Suharsimi. (2016). Manajemen Penelitian. Jakarta: Rineka Cipta.

Bungin, Burhan. (2013). Sosiologi Komunikasi: Teori, Paradigma, dan Diskursus Teknologi Komunikasi di Masyarakat Edisi Pertama (Cetakan Keenam). Jakarta: Kencana.

Feist, Jess \& Feist, Gregory J. (2014). Teori Kepribadian Edisi 7. Jakarta: Salemba Humanika.

Hurlock, Elizabeth. B. (1980). Psikologi Perkembangan Suatu Pendekatan Sepanjang Rentang Kehidupan (Edisi Kelima). Jakarta: Erlangga.

Idrus, Muhammad. (2009). Metode Penelitian Ilmu Sosial Pendekatan Kualitatif dan Kuantitatif Edisi Kedua. Jakarta: Erlangga.

Jahja, Yudrik. (2012). Psikologi Perkembangan Edisi Pertama. Jakarta: Kencana.

Larsen, Randy., \& Buss, David. M. (2018). Personality Psychology Domains of Knowledge Sixth Edition. New York: McGraw-Hill Education.

Mashek, Debra J \& Aron, Arthur. (2004). Handbook of Closeness and Intimacy. New Jersey, London: Lawrence Erlbaum Associates.

Naibaho, Hotnatalia. (2013). Faktor-faktor yang Mempengaruhi Pernikahan Usia Muda (Studi Kasus Di Dusun IX Seroja Pasar VII Tembung Kecamatan Percut Sei Tuan Kabupaten Deli Serdang). Jurnal Universitas Sumatera Utara.

Papalia, Diane E., Olds, Sally Wendkos., \& Feldman, Ruth Duskin. (2009). Human Development Edisi 10. Jakarta: Salemba Humanika

Undang-undang Nomor 1 Tahun 1974 Tentang Perkawinan

Wiley, John., \& Sons, Inc. (2008). Child and Adolescent Development An Advance Course. New Jersey: United States of Amerika Hoboken.

Yusuf, A. Muri. (2014). Metode Penelitian kuantitatif, Kualitatif, dan Gabungan. Jakarta: Kencana. 